\title{
Malay Narratives in Nanyang Travel
}

\author{
Wue Hiong Ser and Chwee Fang Ng* \\ Department of Foreign Languages, Faculty of Modern Languages and Communication, \\ Universiti Putra Malaysia, 43400 Serdang, Selangor, Malaysia
}

\begin{abstract}
"Nanyang” 南洋was a general term used by the Chinese for Southeast Asia before World War II. After the 19th century, the Chinese moved to Nanyang in succession. Located at the centre of "Nanyang", the Malay Peninsula and Singapore became the gathering place of the Chinese at that time and they unexpectedly encountered the indigenous Malay civilisation, thus arousing cultural interaction and immersion. In the 1920s and 1930s, a large number of Chinese literati came to the south for various purposes such as seeking relatives and friends, travelling, investigating, or settling down for a long time, and they recorded the experiences of what they saw and heard in Nanyang in travel records or books. The "Nanyang Youji" 南洋游记 (Nanyang Travels) mainly recorded the customs and anecdotes of the Nanyang society. It is rich in content, diverse in subject matter, and large in volume. It also has a unique writing style, with great literary, historical, and even cultural anthropology value. Although the content of "Nanyang Youji" is mainly based on Chinese society and

ARTICLE INFO

Article history:

Received: 23 July 2020

Accepted: 19 October 2020

Published: 25 December 2020

DOI: https://doi.org/10.47836/pjssh.28.4.45

E-mail addresses:

wuehiong@upm.edu.my (Wue Hiong Ser)

chweefang@upm.edu.my (Chwee Fang Ng)

*Corresponding author

culture, many of them also contain records of the Malay customs and culture that the author personally witnessed which are thus, very precious. This article reviews several "Nanyang Youji" travel records to gain an insight into the Malay society and the Chinese-Malay cultural interaction from the perspective of the early Nanyang travellers.

Keywords: Chinese-Malay cultural interaction, Malay narratives, Nanyang travel
\end{abstract}

ISSN: 0128-7702

e-ISSN: 2231-8534 


\section{INTRODUCTION}

The term "Nanyang” 南洋 (South Ocean) is a unique feature in Chinese history that can be traced back to the Song Dynasty as early as 700 years ago. Initially, the views on "Nanyang" based on its geographical boundaries were unclear and varied. From the views of ancient navigators to modern folks, the definitions of Nanyang are not exactly the same over the years (Lee, 2006). However, "Nanyang" mainly refers to the southern area of mainland China and it also includes Australia and New Zealand in a broader sense. Up until the end of the nineteenth century, the concept of "Nanyang" was gradually determined. Conceptually, "Nanyang" specifically refers to Southeast Asia (including Hong Kong) and it has a close relationship with Chinese history. For instance, "Going to the Nanyang" was a dream of many generations of Chinese immigrants and it constitutes a collective memory in Chinese history. However, when the Chinese people from all parts of China withdrew their native citizenship and immersed into the local culture up until the 1950s, the name and concept of "Nanyang" gradually faded away and it was eventually replaced by the term "Southeast Asia" (Lee, 2006).

Nanyang was a world dominated by the Chinese. After the nineteenth century, Nanyang was gradually becoming the place where the Chinese gathered, which included Java Island, Siam, and Malaya. Among these regions, Singapore Island and Malay Peninsula have a huge Chinese population and boasts some of the most complete social structures as well as a developed culture and education. The earliest Nanyang immigrants were dominated by low-class labourers. In the early twentieth century, they were deeply influenced by China's political situation, especially the Chinese Revolution in 1911 (Yen, 1976) and the May Fourth New Culture Movement in 1919 (Choi, 2019) which strongly promoted social and cultural reformation in Nanyang. With the boom of Chinese schools in various places, a large number of literati and scholars traveled to the south to live and promote the Nanyang culture (Guo, 2019; Jin, 2013). Many of these scholars, through the recommendation of their relatives and friends, taught at Chinese schools and some worked as editors or writers for Chinese newspapers. Many of them also participated in cultural and educational programmes to promote cultural, literary, and artistic creations (Jin, 2013). There were also many people who came to Nanyang for sightseeing and to explore the area.

The 1920s and 1930s represented the peak period for literati who came to the south from China (Guo, 2019; Jin, 2013). Whether it was for long-term settlement or a short trip, Nanyang was always an interesting and new destination for these people due to its different landscape and unique customs that were much varied from their home country, China. Many of them fondly wrote about their experience of Nanyang and several of these texts had been used in travel journals or poems published in newspapers and magazines, while some were published in books. 
Although some of these publications were research-oriented, they were classified as travel documentaries (Xia, 2010). However, this documentary contains information of a rich cultural heritage, including its history, cultural anthropology, local chronicles, literature, and other related content. It has high academic value and contains important material for studying the Singaporean and Malaysian Chinese society before World War II.

The main purpose of this article is to investigate the description and perception of Malays and its culture by Chinese literati in the 1920s from the relevant records in Nanyang travel notes. This article will examine several aspects such as Nanyang scenery, the Malay folk culture, the Malay drama shows and Chinese-Malay cultural interactions.

\section{LITERATURE REVIEW}

According to the preliminary statistics of Yan (2011), there are at least 262 kinds of Nanyang monographs left in the early years. Judging from the contents, they included history, geography, humanities, political economy, and natural sciences. If newspapers, magazines and other related articles are included, the number will be even more encouraging and impactful.

Among these plentiful Nanyang literature, travel documentaries are the main essential part. Some of the well-known travel documentaries are Hou Hongjian's (1920) 侯鸿鉴 Nanyang Lvxingji 南 洋旅行记 (Travel Notes of Nanyang),
Liang Shaowen's (1924) 梁绍文 Nanyang Lvxing Manji 南洋旅行漫记 (The Travel of Nanyang), Song Yunpu's (1930) 宋蕴璞 Nanyang Yingshu Haixia Zhimindi Zhilve 南洋英属海峡殖民地志略 (British Straits Colony Chorography in Nanyang), Liu Xunyu's (1930) 刘薰宇 Nanyang Youji 南 洋游记 (Nanyang Travels), Huang Qiang's 黃強 (1930) Malai Hongxuelu 马来鸿雪录 (The Traces in Malaya), Xu Jie's (1931) 许 杰 Nanyang Manji 南洋漫记 (also known as “Coconut and Durian"), Zheng Jianlu's (1933) 郑健庐 Nanyang Sanyueji 南洋三 月记 (Nanyang In March), Zhao Guanhai's (1933) 招观海 Tiannan Youji 天南游记 (Tiannan Travels), Liu Renhang's (1935) 刘仁航 Nanyang Youji 南洋游记 (Nanyang Travels), Xu Han's (1937) 许瀚Nanyang Congtan 南洋丛谈 (Nanyang Talks) as well as many other articles, thus representing a large enough number to form a unique “Nanyang Youji” 南洋游记 (Nanyang Travels) documentary.

"Nanyang Travels" is mainly a description of what was seen and heard during their journey based on the author's distinctive emotions and personal perspectives. Although the subject is mainly focused on Chinese society, it contains records of the lifestyles outside of the Chinese society such as the clothing, food, shelter, travel, historical stories, customs, and myths of the Malays, and even the indigenous people (Orang Asli). The topics are quite diverse, and it can be used as research material for the Malay society and their culture during the early years. These records are valuable research materials that 
offer insight into their cultural heritage as well.

In the past ten years, the Chinese academic community realised the value of this travel material and started to conduct more studies on this documentary. However, the results were relatively sparse as it mainly focuses on relevant studies regarding the Chinese social culture, Nanyang outlook, and Chinese literature. For example, Xia Jing's (2010) Yuwang Yu Sikao Zhilv Zhongguo Xiandai Zuojia De Nanyang Yu Yingmei Youji Yanjiu (Journey of Desire and Contemplation: A Study of Nanyang and England/America Travelogues by Modern Chinese Writers) uses Nanyang and Anglo-American travel notes to compare their extra-territorial imaginations; Xue Liqing's (2016) “Cong Danggui Dao Liulian: You Quyu Wenhua Fuhao Kan Nanyang Huaren De Bentuhua Licheng" ("From Angelica to Durian: Investigation on Localisation of Nanyang Chinese Based on the Culture Symbolisation") mainly discusses the topic of Chinese localisation from the travel materials; Zhong Shaohua's (2018) "Jindai Zhongguoren Yanzhong De Nanyang" ("Nanyang in the Eyes of Premodern Chinese") is a typical research of the Nanyang View of the modern Chinese scholars; Chong's (2018) "Youli Nanyang: Mahua Sanwenshi De Qidian" ("Traveling to the Nanyang: The Starting Point of the History of Prose in Malaysian Chinese") uses this type of travel records to explore the origin of the history of Malaysian Chinese prose. Although these studies make good use of the Nanyang Travels, information on topics other than the Chinese society based on the Nanyang Travels documentary is sufficiently lacking.

\section{METHOD}

The purpose of this study is to gain a preliminary insight into the Malay social culture from the perspective of Nanyang travellers through the selected Nanyang travel records.

Content analysis was the main research method in order to analyze and interpret the relevant historical documents. By using content analysis, the data were systematically collected from relevant texts. The researchers discussed the related records of Malays, analyzed and commented on the characteristics of Malays and its culture, as well as the perceptions and meanings contained therein. On top of that, the researchers comprehensively examined the Malays images and also the cultural interactions between Chinese and Malay from the perspective of Chinese in the early twentieth century. Firstly, we used the four themes of Nanyang scenery, the Malay folk culture, the Malay drama shows and Chinese-Malay cultural interactions as the starting point for the discussion. Secondly, by observing the actual writing of the authors, we discussed their feelings towards Malay culture through their wording presentation and evaluation in the texts. Finally, we examined and analyzed the presence, meanings as well as the relationships between Malay images and the imaginations of authors in their writings, attempting to point out the meaning of the 
images, ultimately drawing an appropriate conclusion on them.

As mentioned above, there are many published records about Nanyang travel notes, but this article mainly focused on two travel records, namely Liang Shaowen's The Travel of Nanyang in 1924 and Song Yunpu's British Straits Colony Chorography in Nanyang in 1930 as the main source of reference. This study also refered to other travel records for complementing and verifying Liang and Song's work when necessary. Liang and Song's work are exceedingly meaningful and representative. In addition to its deep value as travel notes on Southeast Asia, these two works intentionally record observations on Malay culture and customs, some of them are very well described in detail, and the two works were being produced almost at the same period of time. This would profoundly reflect the views of Chinese people on Malays and its culture in the early twentieth century.

In 1920, Liang Shaowen departed from Shanghai to the Malay Peninsula and travelled to Singapore, Malacca, Kuala Lumpur, Ipoh, and Penang as well as other places. During this period, he also visited Indonesia, Java, Sumatra, and other places to investigate the Chinese education and industrial profiles as well as visited representatives of business, education, and politics from all walks of life. In 1924, his travel experience was published as "The Travel of Nanyang". This book has been highly praised by the academic community because it records many first-hand materials obtained from investigation and review, as mentioned by A Ying, "This book was considered the best among the travel literatures at the time" (1935, p. 348). Thus, it has become a much-discussed work in academia. There are 103 chapters in the book, observation records on Malay culture are scattered among the chapters. Although the proportion is not huge, it is very precious and informative.

On the other hand, Song Yunpu went southward to the Malay Peninsula in 1925 to visit several states of the peninsula. He visited seniors from all over the country and collected cultural and educational information, historical customs, and other materials of the Chinese community as well as official statistics and transportation schedules. After three and a half years of travelling, he published the 'British Straits Colony Chorography in Nanyang' article in 1930 that also acted as a travel note representing a human geographical survey. This travel note is composed of three sections, each containing eight chapters. The first section is travel note of Singapore, the second is travel note of Penang, and the third is travel note of Malacca. From the perspective of historical data, this article is much more informative than The Travel of Nanyang. However, it has not been highly valued by the academic community. It is also worth mentioning that although this book is mainly based on the Chinese community, it contains many Malay social and cultural materials collected by the author himself. 
In addition to these records which scattered from various chapters, there are even some chapters particularly on the Malays in the third section. This includes "A Brief Review of Malay Species", "Malay Nature", "Malay Life and Habits" (such as food, clothing, housing, weddings, funerals and Ramadan), "Malay weaving industry", "Malay sword manufacturing", "Malay pottery", "Malay metal products", "Malay sculptures", "Malay embroidery", and "Malay straw mat and basket manufacturing" (section 3, 24-35). This book may be considered as a brief review of Malay ethnography.

In short, the Malay social and cultural chapter in Liang's work is a random record of his experiences during the journey and it represents the Malay community from the perspectives of ordinary Nanyang tourists. And Song's work is a systematic collection of records which also expresses the personal emotions of the author. This study is mainly focused on text analysis rather a comparison of these two travel records. Based on the two writings by Song and Liang, it is thought that the information gathered can complement each other and present a better narrative of the Malay community based on the early Nanyang Travel Records.

\section{RESULTS AND DISCUSSION}

\section{Nanyang Scenery and Its Image}

The ancient Chinese concept of "southern" was mainly referred to as the southern wasteland where the Nanman tribes lived. Its position gradually moved southward with the expansion of political territory and cultural geography during the past dynasties. The concept of "Nanyang" established in modern times extends far beyond the mainland, whereby it is farther away than the traditionally recognised "Within the Four Seas" 四海 (origins from "Changdi” 常棣, The Book of Songs 诗经 that refers to the land of enlightenment of the son of heaven). Therefore, the term "Nanyang" is said to represent the ultimate view of the South.

In the 1920s of the twentieth century, China experienced the baptism of the May Fourth New Culture Movement in 1919. The literati started to possess with international perspective and modern thoughts. At that time, China was politically divided by warlords, political darkness, social disruption, and the decline of the economy, the literati lost their confidence in their own culture. Meanwhile, the British colonized Malaya needed a lot of labor to open up, thereafter Chinese schools were established in various places, and cultural undertakings also flourished. These are the main factors attracting many literati and scholars to look for opportunities in Nanyang.

From the perspective of modern Chinese literati, "Nanyang" followed the concepts and understanding of traditional southern rural areas, despite having some differences. Although the Chinese literati who travelled to the south inevitably displayed a sense of cultural superiority to the southern ethnics, unlike the traditional concept, they no longer have the mentality of despising the South, 
they were always singing praises about the weather, scenery, and native people of Nanyang. The biggest difference between the modern literati and the traditional view of the South was that there was no longer an aim "to propagate and educate the South" as the indigenous people and their culture in Nanyang are regarded as "exotic customs".

Nevertheless, the "Nanyang" mentioned in these travel notes was first and foremost based on their natural phenology, whereby a tropical climate was described as well as fertile land and rich products. Let us take a look at the Nanyang phenology described by Liang Shaowen (1933):

Nanyang has a very good climate, with wind and rain. It has really good weather conditions for crops as I have mentioned previously. With a blessed and beautiful climate, the land is fertile and the production is extremely rich. There are betel nuts, coconuts, bananas, and millet everywhere, and there is not much of farm work needed to produce abundant crops. Other produce such as cereals and vegetables just need to be seeded and harvested. What a blessing as this does not happen elsewhere or in other places. (p. 43).

This is a typical image portrayed of Nanyang: "excellent climate", "fertile land", and "rich production". In the context of these three elements, even if you don't work, you can sit back and watch the harvest all year round. Compared to China where land was scarce and products were depressed at that time, this place is undoubtedly a paradise. Once again, let us refer to the Nanyang written by Chen Lianqing (1962) during the same period:

The scenery of the land here is not that discouraging. Look, the green coconut groves, thick rubber estates, flourishing plantains, and towering old trees look really lovely. Accompanying the rain-rich climate tropical life is an autumn weather “一雨便成秋yì yǔ biàn chéng qiū" ("a rainfall creates an autumn" and hence, whenever it rains, the temperature falls and it becomes an autumn climate, what a cooling and beautiful weather) which seems very poetic. (Chen, 1962, p. 35).

The Nanyang scenery described by Chen is quite similar to what was described by Liang Shaowen: coconut grove, rubber estates, plantain, old trees, tropical, and rainy. If durian, which is not previously mentioned by Liang and Chen, is added, it can form a group of distinct Nanyang symbols. In particular, coconuts and durian often became important representative symbols as described in Xu Jie's (1931) book that was even named as "Nanyang Man Ji" (also known as "Coconut and Durian").

When these Nanyang images were described based on the literati's emotions, they were inevitably expressed with a form of exotic romantic feelings. Chen said that the "lovely scenery" of the Nanyang land is compatible with the culture of Zhongyuan 
中原 (Central Plains) ${ }^{1}$ as both places are relatively poetic and beautiful. Tropical beauty and romance meet here, and after a long time of immersion, he fell in love with this land. In the "Nanyang Tour" travel notes written by Wang Bojin (1936) in the 1930s, many poetical illustrations were used in his work. He concluded:

I love Nanyang. Loving Nanyang and loving Jiangnan 江南 ${ }^{2}$ are based on different emotions; the love for Jiangnan is compassion, and the love for Nanyang is respect...... Nanyang is located in the middle of the endless sea. The weather displays the tenderness and warmth of nature, it has summer days throughout the year with "a rainfall creates autumn", that's truly Nanyang! The coconut tree is the most significant characteristic of Nanyang. A solitary stem is standing in the blue sky, with peacock hair gathering on the top, and thick and sparse long leaves with some

1 "Zhongyuan 中原 (Central Plains)" is the traditional view of Chinese people on humanistic geography, which means in the central of the world. The geographical area mainly in the middle and lower reaches of the Yellow River, it is the main birthplace of Chinese civilization and the essence of Chinese culture. This region symbolizes the orthodoxy of Chinese culture.

2 “Jiangnan 江南” is also a traditional Chinese view on humanistic geography, which mainly refers to the area of the south and the lower reaches of the Yangtze River. The climate is different from the northern "Central Plains", it's very unique and mild. Thus, this has formed a gentle, graceful, and romantic cultural scenery and geographical image. giant coconuts between the petioles. Sometimes the thick green leaves sweep the sky into a clear shade, and between the petioles, there are some giant fisting coconuts. Sometimes the sparse shots stick into the clear distant sky, a unique style that is not observed in temperate countries. (Wang, 1936, p. 23).

By depicting the climate and coconut trees as important symbolic elements, the "That is truly Nanyang" tone is full of romantic sentiment and that is why the author fell in love with Nanyang. It is also worth noting here that the author used Jiangnan to compare with Nanyang, thus indicating the cultural comparability between these two regions. Song Yunpu (1930) also compared Nanyang with Jiangnan:

Far from the village, I saw some people transplanting paddy in paddy fields. The Malay women were wrapped in purple, yellow, and pink yarns, and they worked hard in the paddy field. From afar, they seemed charming and beautiful. Their tops (wrapping cloths) had attractive colours, reflected by the green rice seedlings. They were just as beautiful as the picture, and there is no difference from the painting. The women of Jiangnan in my country and the scenery of planting paddy, their beauty is incomparable. After a long observation of the beautiful paddy fields, I was truly happy and joyful. (section 2, p. 114).

In Song's trip to Bayan Lepas in Penang, he was deeply attracted and amazed by the 
scenery of the paddy fields there and he unknowingly compared it with the Jiangnan pastoral fields. Although the paddy field scenery is not unique to Nanyang, it was one of the images that described the beauty of Nanyang and it was often written in travel notes. While the Jiangnan pastoral fields were uniquely beautiful, the Nanyang fields were thought to be romantic and affectionate. Hence both were comparatively charming and undoubtedly brought praises and enthusiastic comments to the Malay pastoral scenery and farmhouse sentiment.

In short, although Nanyang is mainly known by the Chinese, it is the ecology of the Malay Archipelago outside the Zhongyuan (Central Plains) region; the landscape in the travel notes is full of Malay emotions and feelings. The two key images of Nanyang, namely "enthusiasm" and "prosperity" have also formed the basis of the Malay sentiment in the eyes of Chinese literati.

\section{Graceful Malay Folk Culture and Malay Beauty}

Under such natural conditions of material abundance, it presents a simple form of life that is indisputable. Regarding the Malay society and culture, Liang Shaowen (1933) wrote this statement: "Always going from simple to simple" (p. 44) This sentence can have two meanings, whereby one has a negative meaning that refers to the living conditions of Malays which depict the backwardness in their character, a trait commonly viewed by the
European colonists at the time; the other is the meaning of appreciation that refers to the simple Malay life and it depicts characters of being contented and happy, simple and optimistic, and not being influenced by utilitarian; it is truly a model for mankind which is to be close to nature.

While the tropical weather represents enthusiasm, the abundant natural resources have made Nanyang a prosperous and comfortable place, despite the relaxing pace of life. Thus, these features have exuded a soothing and romantic charm. The feelings and imaginations of this beautiful sense were reflected in Nanyang Travels from time to time, and there is even full of appreciation displayed for the Malay folk culture.

The paddy fields around Malaya left a good impression on Song Yunpu (1930). He spoke highly of the scenery of paddy fields in his travel notes. While he was travelling in Malacca, he looked up and down along the paddy fields. To him, the paddy field was like a rolling rice wave and it made him think of the idyllic scenery in Jiangnan, China and praised the scenery and the people of Nanyang:

The islands of Nanyang are areas that are prone to rice production, with Malacca being one of the popular paddy producers in the world. The method of planting is to divide the land into fields, transplant the seedlings to the fields, and irrigate with rainwater. There is no need to ditch and draw as there will be rain in a few days' time.

Paddy fields belong to the native Malays, particularly to those who are 
healthy, physically tough, and adaptive to nature. When working in the paddy fields, the women display their utmost diligence. During the transplanting or harvesting season, these Malay women wear colorful silk scarfs and work hard in the field. They focus on their work and have no time to look around. “ 其劳动之勤奋, 亦有不可及者 (qí láodòng zhī qínfèn, yìyǒu bùkějí zhé)", their diligence and assiduousness are incomparable to no one else. Malay women, with their tanned complexion, look beautiful and charming. Whether they stand up or rest, they always look beautiful and graceful from afar the paddy fields. Even when they sing, it was audible, and the melody was pleasant to the ears. This situation was similar to Jiangnan in my country. (Song, 1930, section 3, p. 64).

Song first pointed out that the Malaccan paddy fields had no artificial water conservancy and relied on wind and rain. This was a typical Nanyang climate and it was very conducive for planting. Subsequently, Song's writing was mainly focused on narrating Malay topics. The farmers in the fields were all Malays and the beauty of the Nanyang countryside was attributed to the values demonstrated by the Malay farmers, especially the hard-working Malay women in the paddy fields. Song spoke highly about them and promoted the diligence and hard work of the Malay women. According to him, the assiduousness of the Malays was incomparable to other ethnic groups. The image depicted in the Nanyang Travels was very different from the prevailing view of the laziness of the Malays.

In addition to the virtues of hard work and diligence, the Malay women were praised for their skills and talents in arts and their gracefulness was always featured in the Nanyang Travel notes. For example, Liu Xunyu's Nanyang Travels (1930) used a passionate description to praise the Malay beauties:

Malay beauties have their own characteristics..... In between two scenes of the Malay stage performance, there is always a dance performance. The so-called dancing is provocative, and it often creates a sense of beauty. Most importantly, they have a nice figure and shape, and their skin color is healthy and sweet. As for me, they are charming and incomparably attractive. The darker skin tone adds to the mystery of these women. On top of that, their thick black hair and eyebrows, as well as the big, clear eyes, also increase the strength of the tenderness and enchantment of these Malay women. Their lips are slightly thicker and wider, and their smile while dancing seems to be very sweet and seductive. Due to the well-developed muscles throughout the body, the whole body seems fit and the legs and natural feet allow for a stable posture. Additionally, there is a lot of tenderness and softness in them. What are the indispensable conditions for 
their beauty in the eyes of the Malays? I have no idea. What I feel is beautiful about her is her tenderness and strength. They represent the beauty between the East and the West, just like the place where they live, which is in between the east and the west. This may not be the best statement, but there is always a lot of truth in it and it makes sense! (pp. 40-41).

The author described the beauty of Malay women through their dancing performances. The beauty of this tropical atmosphere which is found in Malay women is very different from the Chinese aesthetics of the Northern Mongoloid women. The beauty of the Nanyang Malay women is all about their beautiful tanned body, thick hair, clear black eyes, mellow red lips, and graceful dance steps. They could not help but admired the skills and talents of these Malay women, and that was beyond all the words that could be described by the author, as it was either the beauty of the Eastern or the Western women with a standard feature of beauty, that is "softness".

The literati came to Nanyang with curiosity and they often wrote down what surprised and amazed them. Some of these include the folk customs of the Malay diet that are no longer practiced today. For example, the betel nut culture is one of the remarkable examples. Liang Shaowen (1933) once recorded this phenomenon:

They (Malays) are very fond of betel nuts and it does not leave their mouths all day long, so their lips are always red. At first, I saw them all vomiting blood, gosh! Later, after a long stay, I realised that the red saliva that they spit was caused by eating the betel nuts. (p. 44).

It can be observed that the Malays had the habit of chewing betel nuts throughout their early years. Today, many indigenous people in the Malay Archipelago still have this habit, thereby indicating that this habit was a common ancient food culture in the region. Liang's description was just a general observation. On the other hand, Song Yunpu (1930) further described the background and reasons for this food culture:

The habit of chewing betel nuts by the Nanyang people has a long history. There are many types of protozoa and cholera bacteria in the tropical waters, and the natives are constantly drinking raw water due to the climate. Hence, the cholera epidemic is rampant and it often kills people. Since food is perishable, the residual dirt between the teeth is very suitable for the growth of bacteria and it will cause tooth decay after a long time. Chewing betel nut and a little bit of lime has the function of sterilising and protecting the teeth without harming the human body. Therefore, chewing betel nut is one of the sanitation methods used by the natives. (section 3, p. 17).

Song Yunpu's narrative is more specific and meticulous, and it has a scientific explanation, thereby emphasising that this 
is a method for people living in tropical environments to maintain oral hygiene. From this narrative, the characteristics and value of Song's travel notes can be observed.

\section{Malay's Talent in Drama Show}

The two elements of the Nanyang beauty presented in the Nanyang travel notes are the Malay women and their talents and skills in performing art. The Malay drama performance was the most convincing attribute that always received a lot of praises by the literati. It is evident that Liang Shaowen or Song Yunpu spent a considerable amount of time introducing the Malay dramas and gave very high evaluation and rave reviews about it. After watching the Malay dramas, Liang Shaowen (1933) described the following impression:

Their dramas (referred to as Malay dramas) won praises from many audiences and I have even mentioned that they were much better than the Chinese vernacular dramas! (pp. 182183).

Judging from the phrase "praises from many audiences", Malay dramas gained a wide appreciation from the Chinese at that time. Liang also thought it was much better than the Chinese vernacular dramas. He specifically compared it with Chinese vernacular dramas, introduced the performance characteristics of Malay dramas, and highlighted its strengths. As for why Malay dramas were "more mournful and melancholic, but less heroic and chivalrous", Liang believes that this was "all because of their environment and ethnic opinion; they were under the supervision and the interference of conquerors. Under the intervention and interference, every script had to undergo an extremely strict inspection" (Liang, 1933, p. 183). Although there were only a few words written by the author, they inadvertently kept the records of the colonial official's rigorous examination of their folk culture.

As for Song Yunpu's (1930) comments for Malay dramas, he also praised them highly compared to the Chinese and Western dramas. There is a passage in the travel notes of him describing a raving comment that is very enthusiastic:

(Malays) They are good at acting, and those who have heard and seen their dramas will be touched, and they will fall in it, thus feeling reluctant to leave and always thinking about the show. I lived in Singapore for a long time and I have heard of Malay dramas. I watched them occasionally. At first, I was in doubt over it. However, after the first view, it changed my mind and I was deeply inspired by their performance. “视中国戏与西洋戏, 有过之无不及 ( shì Zhōngguó xì yǔ xīyáng xì, yǒu guò zhī wú bù jí ) ", even the Chinese and Western dramas are far behind and they are incomparable to the Malay dramas. I enjoyed watching them from time to time and I appreciate the effort and enjoyment of their performance. (section 1, p.152) 
Watching the Malay dramas can literally make people "fall in it, and yet feel reluctant to leave and keep thinking about the show" (section 1, p. 152). This is the charm of the Malay dramas. Additionally, Malays are not only capable of performing dramas, but they are also good at performing authentic Chinese dramas, which is both surprising and exciting. Let's take a look at Song's description below:

There are a lot of beautiful traits and strengths of the Malays. The Malays are talented in acting and they can even perform the Chinese dramas. Among the Chinese and foreign dramas, Malay dramas have their uniqueness. What is amazing is that the Malays can even perform Chinese dramas! Due to the majority audience being overseas Chinese $^{3}$, one or two Chinese dramas have been played during the stage performance to cater to the Chinese audience, and this was very much welcomed by the overseas Chinese...... At the time of the performance, both men and women wore Shanghai-style fashionable clothes, sang Chinese songs, used Cantonese, and they became popular. The ability of the Malays to perform is indeed evident based on their profound talents. The audiences were very much amazed by their ability and talents... (Malays) are good at acting

3 The original text is “华侨” (huáqiáo), which means Chinese nationals living overseas. The English translation is generally translated as "Overseas Chinese". Please refer to Wang Gung Wu's discussion (Wang, 2005). and the audiences were very fond of their dramas. Their dramas were always fascinating and entertaining. (Song, 1930, section 1, p. 150).

The Malays have performed Chinese dramas, wore Chinese costumes, and even used Chinese dialogues. It can be said that they are very skilful and talented in imitating. They are also popular, well known, fascinating, and admirable by all. Song praised the Malays. The Malays had a good talent for acting and this was believed to be the prevailing view of the people at that time.

\section{Chinese-Malay Cultural Interactions}

To cater to the Chinese audience, the Malay performing arts troupe played Chinese dramas that depicted a real image of Nanyang: a cultural field where the Chinese and Malay met. The ChineseMalay civilisation met unexpectedly here, forged relationships, influenced each other, and learned from each other. This historical phenomenon has been faithfully recorded from time to time under the curious vision of the literati in the South.

Liang Shaowen's (1933, p. 145-148) The Travels of Nanyang has a section of "The localised Chinese" which describes his visit to Tun Tan Cheng Lock, a representative of Baba in Malacca. Liang also meticulously described the diets, clothing, and the lifestyle of the Baba. The writing provides a significant historical cultural essence of the Baba for future generations. Different ethnic groups in Nanyang lived together as the "Malay language is simple and it is an 
easy language to learn, and it is indeed the lingua franca of the community" (Song, 1930, section 3, p. 39). On the other hand, the Chinese dialect was also influenced by the Malay language, and some travel notes recorded the text or special sections, thus serving as a valuable material for studying the history of the Chinese language. To gain an insight into the cultural exchanges between the Chinese-Malay ethnic groups in the Nanyang community, here is one example of women's clothing in Nanyang described by Song Yunpu (1930). When he first arrived in Singapore, he noticed that the Chinese women's clothing and hair accessories were different from those in China:

When I first arrived in Singapore, I saw many of our overseas Chinese women who put up hair buns or coils on their heads and they dressed in neither Cantonese nor Shanghai costumes. I wondered and asked my friends and they told me that this is the Malay costume. Since we are now part of the natives of the country, we live and mix around with the Malays, and my children and younger generations imitate how the Malays dress up. (section 1, p. 70).

From this description, it can be observed that the Chinese women at that time loved Malay costumes and followed the trend. Moreover, Chinese society was greatly influenced by the Malay culture. Therefore, it can be summarised that the close relationship between the Chinese-Malay society was established since that time.

\section{CONCLUSION}

This article discussed the Malay narratives and images depicted in Nanyang's Travel records, a relatively new attempt in revisiting the cultural history of Nanyang. At present, the discussion of Nanyang Travels in the academic world is mainly focused on the issues of Chinese society. Hence, the Malay fragments in Nanyang Travels described through the writings were merely just a glimpse of their observations or experiences. Nevertheless, it reflects the customs of Nanyang from the perspective of Chinese literati in the early years as well as provides a perspective for observing the Malay culture. Hence, these narratives contributed significantly to this study.

The Malay image depicted from the Nanyang perspective is quite different from the Malay image derived from the perspective of Western "orientalism" of the same era. Although Nanyang is an "exotic" location for both China and the West, the Chinese came to Nanyang with different motives as compared to the Europeans who came to Nanyang. The Europeans came to Nanyang to explore, or to find resources or even to conquer and colonise. It is a spirit of conquest that is full of the hunt for adventure, prying, penetration, and conquering. On the other hand, the Chinese were domestically bankrupt in their home country and came to Nanyang purely to make a living. Although the literati and scholars had a sense of cultural superiority, they did not have the conquerors' dominance and power to control. Instead, they displayed an appreciation of the Malay civilisation 
from the perspective of outsiders. In short, the Nanyang Travels provides a more positive than a negative description of the image of Malays by the Chinese literati and is always accompanied by a bundle of praises.

\section{ACKNOWLEDGEMENT}

This work was supported by the Geran Putra [grant numbers GP/2018/9600400]. Our thanks to two anonymous reviewers for constructive and insightful comments.

\section{REFERENCES}

A Ying. (Ed.). (1935). 中国新文学大系. 史料索 引 [Chronology of Chinese new literature: Historical data and index]. Hong Kong, China: Society of Hong Kong Literature Studies.

Chen, L. Q. (1962). 文艺与地方色彩 [Literature and local features]. In 陈鍊青文集 [Essay on Chen Lianqing] (pp. 34-36), Hong Kong, China: Nanyang Literature and Art Publisher.

Choi, K. K. (2019). 海峡殖民地华人对五四运动的 反响 [The response to May Fourth Movement of Straits Settlement Chinese]. In Y. W. Wong, \& K. K. Phua (Eds.), 五四在东南亚 [May Fourth Movement in Southeast Asia] (pp. 61-71). Singapore: Global Publishing. doi: 10.1142/g443

Chong, Y. V. (2018). 游历南洋: 马华散文史的起 点 [Traveling to the Nanyang: The starting point of the history of prose in Malaysia], 世界华文 文学论坛 [Forum for Chinese Literature of the World], 2018(2), 73-80.

Guo, H. F. (2019). 中国新文化运动在东南亚的传播 [The spread of Chinese new cultural movement in Southeast Asia]. In Y. W. Wong, \& K. K. Phua (Eds.), 五四在东南亚 [May Fourth Movement in Southeast Asia] (pp. 79-118). Singapore: Global Publishing. doi: 10.1142/g443
Hou, H. J. (1920). 南洋旅行记 [Travel notes of Nanyang]. Wuxi, China: Xicheng.

Huang, Q. (1930). 马来鸿雪录 [The traces in Malaya], Shanghai, China: The Commercial Press.

Jin, J. (2013), 马华文学的发生与发展（19191965 ) - 以南来作家的身分认同与转变 威讨论对象 [The emergence and development of Malaysian Chinese literature (19191965): Focusing on the indigenization and transformation of Chinese immigrant writers in Malaysia]. 东华汉学 [Dong Hwa Journal of Chinese Studies], 18, 377-424.

Lee, C. S. (2006). 一个南洋, 各自解说: “南洋” 概念的历史演变 [One Nanyang, different interpretations: A historical evolution of the concept "Nanyang"]. 亚洲文化 [Asian Culture], 30, 113-123.

Liang, S. W. (1933). 南洋旅行漫记 [The Travel of Nanyang]. Shanghai, China: Chung Hwa Book Company.

Liu, R. H. (1935). 南洋游记 [Nanyang travels]. Singapore: Nanyang Bianyishe Society.

Liu, X. Y. (1930). 南洋游记 [Nanyang travels]. Shanghai, China: Kaiming Bookstore.

Song, Y. P. (1930). 南洋英属海峡殖民地志略 [British Straits colony chorography in Nanyang], Beijing, China: Yunxing Company.

Wang, B. J. (1936). 南洋巡礼 [Sightseeing tour on Nanyang]. In Z. Wu (Ed.), 注释外国游记选 [Annotation on The Selected of Foreign Travels] (pp. 23-32). Shanghai, China: Chung Hwa Book Company.

Wang, G. W. (2005). “华侨”一词起源诠释 [An explanation of the origin of the word "overseas Chinese”]. In G. W. Wang (Ed.), 移民与兴起的 中国 [Immigration and the Rising China] (pp. 154-167), Singapore: Global Publishing. doi: $10.1142 / 9789814285230$ 
Xia, J. (2010). 欲望与思考之旅: 中国现代作家 的南洋与英美游记研究 [Journey of Desire and Contemplation: A study of Nanyang and England/America Travelogues by Modern Chinese Writers]. Taipei, Taiwan: Wenshizhe Publisher.

Xu, H. (1937). 南洋丛谈 [Nanyang talks]. Hangzhou, China: Xiandai Bookstore.

Xu, J. (1931). 南洋漫记 [Coconut and Durian]. Shanghai, China: Xiandai Bookstore.

Xue, L. Q. (2016). 从 “当归”到“榴梿”: 由区域 文化符号看南洋华人的本土化历程 [From angelica to durian: investigation on localization of Nanyang Chinese based on the culture symbolization). 台湾东南亚学刊 [Taiwan Journal of Southeast Asian Studies], 11(1), 71-89.
Yan, M. (2011). 民国南洋学的几种话语 (19121949) [Several discourses of the study of Nan Yang during the time of the Republic of China (1912-1949)], 东南亚研究 [Southeast Asian Studies], 2011(1), 90-94.

Yen, C. H. (1976), The Overseas Chinese and the 1911 Revolution. Kuala Lumpur, Malaysia: Oxford University Press.

Zhao, G. H. (1933). 天南游记 [Tiannan travels]. Shanghai, China: Jinan University.

Zheng, J. L. (1933). 南洋三月记 [Nanyang in March]. Hong Kong, China: Chung Hwa Book Company.

Zhong, S. H. (2018). 近代中国人眼中的南洋 [Nanyang in the eyes of pre-modern Chinese], 马来西亚华人研究学刊 [Journal of Malaysian Chinese Studies], 20, 143-178. 